\title{
Quantifying Effects of Seedborne Inoculum on Virus Spread, Yield Losses, and Seed Infection in the Pea seed-borne mosaic virus-Field Pea Pathosystem
}

\author{
B. A. Coutts, R. T. Prince, and R. A. C. Jones
}

First and second authors: Agricultural Research Western Australia, Locked Bag No. 4, Bentley Delivery Centre, Perth, WA 6983, Australia; and third author: Agricultural Research Western Australia, Locked Bag No. 4, Bentley Delivery Centre, Perth, WA 6983, Australia, and School of Plant Biology, Faculty of Natural and Agricultural Sciences, University of Western Australia, 35 Stirling Highway, Crawley, WA 6009, Australia.

Accepted for publication 12 June 2009.

\section{ABSTRACT}

Coutts, B. A., Prince, R. T., and Jones, R. A. C. 2009. Quantifying effects of seedborne inoculum on virus spread, yield losses, and seed infection in the Pea seed-borne mosaic virus-field pea pathosystem. Phytopathology 99:1156-1167.

Field experiments examined the effects of sowing field pea seed with different amounts of infection with Pea seed-borne mosaic virus (PSbMV) on virus spread, seed yield, and infection levels in harvested seed. Plots were sown with seed with actual or simulated seed transmission rates of 0.3 to $6.5 \%$ (2005) or 0.1 to $8 \%$ (2006), and spread was by naturally occurring migrant aphids. Plants with symptoms and incidence increased with the amount of primary inoculum present. When final incidence reached 97 to $98 \%$ (2005) and 36\% (2006) in plots sown with 6.5 to $8 \%$ infected seed, yield losses of 18 to $25 \%$ (2005) and $13 \%$ (2006) resulted. When incidence reached 48 to $76 \%$ in plots sown with $1.1-2$ to $2 \%$ initial infection, seed yield losses were 15 to $21 \%$ (2005). Diminished seed weight and seed number both contributed to the yield losses. When the 2005 data for the relationships between percent incidence and yield or yield gaps were plotted, 81 to $84 \%$ of the variation was explained by final incidence and, for each $1 \%$ increase, there was a yield decline of 7.7 to $8.2 \mathrm{~kg} / \mathrm{ha}$. Seed transmission rates in harvested seed were mostly greater than those in the seed sown when climatic conditions favored early virus spread ( 1 to $17 \%$ in 2005) but smaller when they did not (0.2 to $2 \%$ in 2006). In 2007, sowing infected seed at high seeding rate with straw mulch and regular insecticide application resulted in slower spread and smaller seed infection than sowing at standard seeding rate without straw mulch or insecticide. When data for the relationship between final percent incidence and seed transmission in harvested seed were plotted (all experiments), 95 to $99 \%$ of the variation was explained by PSbMV incidence. A threshold value of $<0.5 \%$ seed infection was established for sowing in high-risk zones.

Additional keywords: epidemic, primary infection, temporal dynamics, thresholds.
There have been many advances in knowledge of the processes by which developing seed becomes infected on the plant (53-55), and in devising sensitive immunological and molecular testing procedures to detect seed-borne virus infection in seed samples $(2,14,29)$. However, scant attention has been given to quantification of the yield losses that arise from sowing seed stocks with different amounts of seedborne infection. What agricultural and horticultural industries need to know is the significance of such sowings in terms of the virus epidemics generated, the seed yield and quality losses likely to occur, and the extent of infection in newly produced seed. This requires knowledge of (i) the degree of risk that substantial losses may arise when seed stocks with different amounts of virus infection are sown and (ii) what constitute acceptable infection threshold levels in sown seed (21, 24,46). Apart from research with Lettuce mosaic virus (LMV; family Potyviridae, genus Potyvirus) $(18,19,49,57)$ in lettuce (Lactuca sativa) and Cucumber mosaic virus (CMV; family Bromoviridae, genus Cucumovirus) in narrow-leafed lupin (Lupinus angustifolius) $(7,8,23-25,28,52)$, examples where seed with different amounts of infection has been sown in sufficient

Corresponding author: R. A. C. Jones; E-mail address: roger.jones@agric.wa.gov.au

* The $\boldsymbol{e}$-Xtra logo stands for "electronic extra" and indicates that Figure 2 appears in color online.

doi:10.1094/PHYTO-99-10-1156

(C) 2009 The American Phytopathological Society field experiments to provide such information are lacking. Limited information is available from field experiments with some other pathosystems $(1,11,12,16,22,30,31,41,44)$ but none of these studies provided sufficient data on losses to be useful in advising farmers whether the risk of economic loss from sowing seed with a low level of virus infection is sufficiently small to be acceptable for their particular risk zone (24).

Pea seed-borne mosaic virus (PSbMV; family Potyviridae, genus Potyvirus) infection of field pea (Pisum sativum) constitutes an important example of a pathosystem where field experiments that provide information on the consequences of sowing different amounts of seedborne inoculum are lacking. Field pea is a cool-season grain legume grown as a food crop in many countries. The virus is nonpersistently aphid borne and several aphid species act as vectors. It has a narrow host range and the principal source of infection for field pea crops is sowing infected seed. Commercial pea seed stocks are rarely free of contamination with it, seed transmission rates ranging from $<0.1$ to $>50 \%$ in individual seed stocks having been found $(2,5,6$, $13,15,20,32,33,35,36,39)$. Available yield loss data comes only from experiments in which pea plants were sap inoculated with the virus. Chiko and Zimmer (9) inoculated plants growing within small rectangular field plots with PSbMV at different growth stages. When dry seed yields from inoculated and uninoculated plants were compared, the yield losses of 11 to $36 \%$ recorded mostly arose from diminished seed weight. In similar experiments, Kraft and Hampton (34) reported seed yield losses of 16 to 
$78 \%$ in different pea cultivars, with greater losses occurring in plants inoculated at an earlier growth stage; Khetarpal et al. (32) recorded yield losses of $\geq 15 \%$; and Ovenden and Ashby (43) obtained a $33 \%$ yield loss in one cultivar but no significant losses in others. In experiments with single-row plots, Makkouk et al. (37) recorded yield losses of 49\%, while Ali and Randles (3) obtained yield losses of 35 to $82 \%$ under glasshouse conditions. Thus, PSbMV has the potential to cause substantial yield losses when all plants are infected early. However, this "worst-case scenario" does not reflect epidemics initiated by large-scale field sowings of infected seed stocks in which aphid vectors acquire the virus from seed-infected plants scattered at random through the crop and spread it gradually to healthy plants so that they become infected at different growth stages.

Although PSbMV is a well-known virus that commonly infects field pea crops, its importance is often underestimated because it causes subtle foliar symptoms that are difficult to see in the field $(32,33)$. Moreover, the seed quality defects that its infection induces, and the resulting decrease in the economic value of seed consignments, tend to be attributed to other causes, such as seed discoloration and blemishes arising from environmental stresses during harvest and seed storage, or infection with fungal pathogens. These seed-quality defects mostly consist of necrotic ring and line markings on the seed coat, malformation, smaller size, and splitting $(13,35-37,39,47,48)$.

The grain belt of southwest Australia has a Mediterranean-type climate with hot, dry summers. Grain legume crops, especially field pea and narrow-leafed lupin, are sown in late fall to early winter and harvested in late spring, and are entirely rain fed. Surveys in the grain belt found that infection with PSbMV is widespread in commercial field pea crops, with seed transmission levels of up to $47 \%$ occurring in commercial seed stocks $(13,35)$. Field experiments in the region evaluated the responses of diverse field pea genotypes to infection with PSbMV, including their susceptibilities and sensitivities to plant infection, seed transmission rates, and seed-quality defects $(13,36)$. However, no yield loss data were available for PSbMV in field pea. In other field studies in the grain belt, narrow-leafed lupin seed with different amounts of CMV infection was sown in large plots at different sites over several years to initiate differential epidemics, in which aphid vectors spread the virus from initial seed-infected plant foci to healthy plants which became aphid inoculated at different growth stages. These studies quantified the effect of CMV infection on seed yield and subsequent seed transmission in harvested seed, and provided information on likely outcomes arising from sowing infected seed stocks under different climatic and rainfall zone scenarios. This enabled establishment of acceptable seed infection threshold levels in sown seed $(7,8,23-25,28)$. This article reports similar studies that used the same experimental design and were done in the same region with PSbMV in field pea. Three field experiments were sown over 2 years at two sites in different locations. Seed stocks with different amounts of PSbMV infection were sown or infector plants were transplanted into plots to simulate different percentages of seed-infected plants. Data were collected under different climatic scenarios on virus spread, seed yield, and infection of harvested seed. Two experiments using additional sites at other locations in another year examined the effects of potential integrated disease management (IDM) scenarios on PSbMV spread and seed infection.

\section{MATERIALS AND METHODS}

Virus isolate, plants, inoculations, and antiserum. Test, culture, and infector plants were grown in insect-proof, airconditioned glasshouses maintained at 15 to $20^{\circ} \mathrm{C}$. Plants of faba bean (Vicia faba) cv. Fiord were grown in washed river sand in pots (culture plants) or jiffy pots (infector plants). PSbMV isolate W1 (35) was maintained in faba bean culture plants by sap inoculation. The sources of PSbMV inoculum in field experiments were infected seed or infector plants of faba bean sap inoculated with isolate W1 before transplanting outside. For sap inoculation, PSbMV-infected leaves were ground in $0.1 \mathrm{M}$ phosphate buffer, $\mathrm{pH} 7.2$, and the sap mixed with celite before being rubbed onto the leaves of plants. Faba bean infector plants were used instead of pea infector plants because they survive transplant shock better when transplanted from the glasshouse to the field. Leaf samples from the faba bean culture of isolate W1 were used as the positive control in enzyme-linked immunosorbent assay (ELISA). The polyclonal antiserum to PSbMV used was from DSMZ, Germany.

ELISA. Field pea leaf samples were extracted singly or in groups of 2 to 10 in phosphate-buffered saline $(10 \mathrm{mM}$ potassium phosphate, $150 \mathrm{mM}$ sodium chloride), $\mathrm{pH} 7.4$, containing Tween 20 at $5 \mathrm{ml} /$ liter and polyvinyl pyrrolidone at $20 \mathrm{~g} /$ liter, using a mixer mill (Retsch, Germany). The sample extracts were tested for infection by double-antibody sandwich ELISA (10). Each sample was tested in duplicate wells in microtiter plates and appropriate PSbMV-infected and healthy leaf samples were included in paired wells as controls. The substrate used was $p$-nitrophenyl phosphate at $0.6 \mathrm{mg} / \mathrm{ml}$ in diethanolamine at $100 \mathrm{ml} / \mathrm{liter}$, $\mathrm{pH}$ 9.8. Absorbance values (at $405 \mathrm{~nm}$ ) were measured in a microplate reader (Bio-Rad Laboratories). Positive absorbance values were always at least 10 times those of healthy sap. Virus incidence was estimated from grouped sample test results using the formula of Gibbs and Gower (17).

General field experiment details. Department of Agriculture and Food Western Australia Research Stations at Avondale $\left(32^{\circ} 06^{\prime} \mathrm{S}, 116^{\circ} 52^{\prime} \mathrm{E}\right)$, Badgingarra $\left(32^{\circ} 20^{\prime} \mathrm{S}, 115^{\circ} 30^{\prime} \mathrm{E}\right)$, Esperance $\left(33^{\circ} 86^{\prime} \mathrm{S}, 121^{\circ} 88^{\prime} \mathrm{E}\right)$, and Merredin $\left(31^{\circ} 31^{\prime} \mathrm{S}, 118^{\circ} 10^{\prime} \mathrm{E}\right)$ were used for the field experiments. These sites are located in different rainfall and geographic zones of the grain belt (Fig. 1). Based on normal timing of aphid flights in relation to late summer or early fall rainfall, Merredin is in a low-risk zone while the other three sites are in high-risk areas $(7,25,26,38,50,51)$. Esperance is the principal field pea production area but the crop is also grown elsewhere in the grain belt. Badgingarra is the warmest site during the growing period and Esperance the coolest. Experiments 1 to 3 examined the implications of sowing seed with different amounts of infection and experiments 4 and 5 examined potential IDM scenarios. Experiments 1 and 2 were duplicates at different sites in the same year (2005). Similarly, experiments 4 and 5 were duplicates at other sites in a different year (2007). Experiment 3 (in 2006) was not duplicated but was at the same site used in the previous year for experiment 1. For each experiment, details of year, site, rainfall zone, sowing date, plot size, number of replications, and seeding rates used are in Table 1. Bimonthly temperature and rainfall data for each site and year when an experiment was done are in Table 2.

Appropriate herbicides were applied to the soil before sowing to prepare weed-free seed beds. All experiments had randomized block designs. They were sown with cone seeders with $18-\mathrm{cm}$ row spacing, and a 10-m wide buffer of canola (Brassica napus) surrounded each plot. Seed of field pea cv. Kaspa was used in all experiments. This cultivar is semi-leafless with stiff stems, has resistance to lodging and pod shattering, and is high yielding, with dun-type seed. PSbMV seed transmission rates in the cv. Kaspa seed stocks used were established by growing out seedlings and testing grouped seedling leaf samples by ELISA as described previously $(7,13,23,28,35,36)$. In experiments 4 and 5 , semi-leafless PSbMV-resistant cv. Yarrum was also used. Grass and broad-leafed weeds growing within plots were controlled using appropriate selective herbicides and rigorous hand weeding; buffers and plot margins were also kept weed-free. Samples were taken from pea plants by walking in a Z- or W-shaped pattern through each plot. Every few paces, one plant was randomly selected, a newly emerged shoot removed, and the shoots placed 
in labeled plastic bags. Sample bags were then stored in a cooler box for transport back to the laboratory, where the samples were tested by ELISA.

Experiments 1 and 2. Because no seed stock with $<0.3 \%$ infection was available, the control treatment consisted of plots sown with $0.3 \%$ infected seed that were sprayed with insecticide at emergence, and then at 28, 56, and 84 days after sowing (DAS) (experiment 1 ) or at $17,38,61$, and 89 DAS (experiment 2 ). The other six treatments were left unsprayed until later and consisted of plots sown with (i) 0.3 or $6.5 \%$ infected seed into which no infector plants were transplanted or (ii) $0.3 \%$ infected seed which had $8,15,22$, or 36 infector plants transplanted into them simulating $0.7,1.1,1.4$, and $2.2 \%$ (experiment 1 ) or $0.6,0.9,1.1$, or $1.7 \%$ (experiment 2) infection, respectively (based on plant densities). Infector plants were introduced into plots at 15 DAS in experiment 1 and at 24 DAS in experiment 2 . The insecticide sprays consisted of combined foliar applications of $\alpha$-cypermethrin (Fastac at $500 \mathrm{ml} / \mathrm{ha}$ ) and imidacloprid (Confidor at
$170 \mathrm{ml} / \mathrm{ha}$ ) in water at 100 liters/ha. Blanket sprays of the same insecticide combination were applied subsequently to all plots at 108 and 122 DAS in experiment 1 and 101 and 115 DAS in experiment 2 to control native budworm (Helicoverpa punctigera) and pea weevil (Bruchus pisorum).

Plant density was counted within each plot on 49 DAS (experiment 1) and 39 DAS (experiment 2) by selecting sections of 15 rows $0.8 \mathrm{~m}$ in length at random. Shoot samples (50/plot) were collected from all plots at 22, 50, 64, 78, 92, and 106 DAS (experiment 1) and 20, 49, 63, 76, and 93 DAS (experiment 2) for testing by ELISA. All plots were harvested and seed yield weighed. For each plot, 1,000 seeds were counted out and weighed.

Experiment 3. Sowing was delayed due to the dry start to the growing season. Because no seed stock of cv. Kaspa with $<0.1 \%$ infection was available, the control treatments consisted of plots sown with $0.1 \%$ infected seed that were either sprayed with insecticide at emergence (18 DAS) and then at 40 and 67 DAS, or

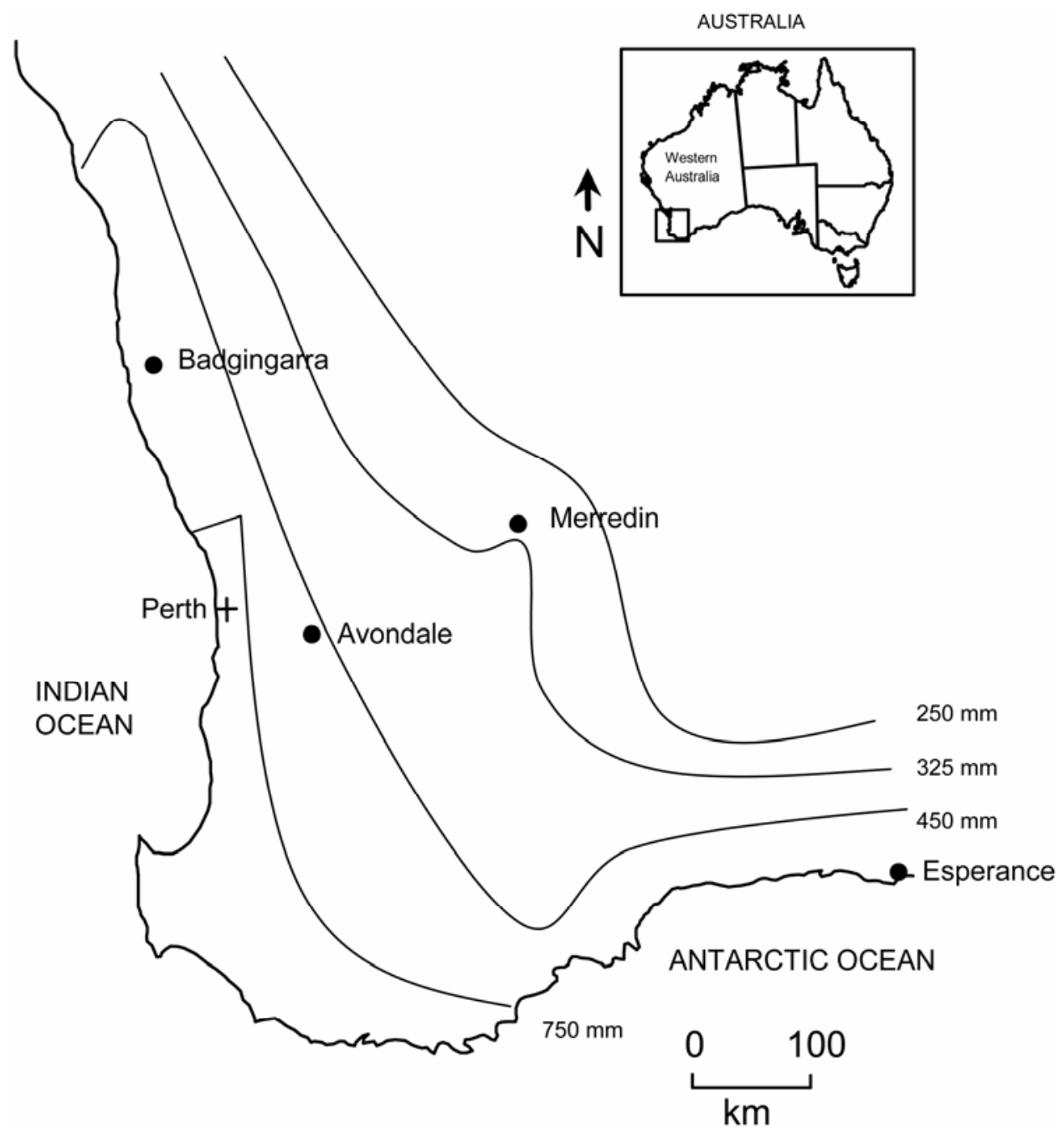

Fig. 1. Locations where field experiments were done $(\bullet)$ and rainfall zones in the grain belt region of southwest Australia.

TABLE 1. General details of field experiments

\begin{tabular}{lclccccc}
\hline Experiment & Year & Site & Sowing date & Plot size $(\mathrm{m})$ & Replications & Seeding rate $(\mathrm{kg} / \mathrm{ha})$ & Grain belt rainfall zone \\
\hline 1 & 2005 & Avondale & 30 May & $10 \times 4.5$ & 5 & 100 & High \\
2 & 2005 & Badgingarra & 2-8 June & $10 \times 4.5$ & 5 & 125 & High \\
3 & 2006 & Avondale & 29 June & $10 \times 5.5$ & 4 & 100 & High \\
4 & 2007 & Merredin & 20 June & $20 \times 5.5$ & 3 & $100 \& 200$ & Low \\
5 & 2007 & Esperance & 29 May & $20 \times 5.5$ & 3 & $100 \& 200$ & High \\
\hline
\end{tabular}

${ }^{\mathrm{z}}$ Rainfall zones: high $=450$ to $750 \mathrm{~mm} /$ year and low $=250$ to $325 \mathrm{~mm} /$ year. 
left unsprayed until later. The other six treatments were also left unsprayed until later. They consisted of plots sown with $0.25,0.5$, $1,2,4$, and $8 \%$ infected seed, seed transmission rates of 0.25 to $4 \%$ being achieved by blending 0.1 and $8 \%$ infected seed in different proportions. The combination of insecticides applied was as in experiments 1 and 2. Blanket insecticide sprays were applied every 2 weeks from 75 DAS until harvest.

Plant density was counted in each plot on 21 DAS by selecting eight sections of rows $1.0 \mathrm{~m}$ in length per plot at random. Shoot samples (50/plot) were collected from all plots as described above at 21, 48, 61, 75, 89, and 103 DAS and tested for PSbMV. All plots were harvested individually. Their seed yields were weighed and then 1,000 seeds were counted out from each of them and weighed.

Experiments 4 and 5. Seed stocks of cv. Kaspa with 0.5 and $8.2 \%$ infection and seed of cv. Yarrum were used. Each experiment had five treatments which were plots sown with 0.5 or $8.2 \%$ infected seed at high seeding rate $(200 \mathrm{~kg} / \mathrm{ha})$ with added straw mulch (2 t/ha) and regular insecticide sprays; plots sown with 0.5 or $8.2 \%$ infected seed at standard seeding rate $(100 \mathrm{~kg} / \mathrm{ha})$ without added straw mulch or regular insecticide sprays; and plots of cv. Yarrum sown at $100 \mathrm{~kg} / \mathrm{ha}$ without straw mulch or regular insecticide sprays. Combined foliar insecticide applications were as in experiments 1 and 2. Treatment insecticide applications were applied at 21, 51, and 82 DAS (experiment 4) or at 23, 42, and 76 DAS (experiment 5). Subsequent blanket insecticide applications were applied at 86 and 110 DAS (experiment 4) and 104 and 128 DAS (experiment 5). Shoot samples (50 per plot) were collected from all plots as described above at 28, 69, and 90 DAS (experiment 4) and 22, 78, 98, and 111 DAS (experiment 5) and tested for PSbMV. All plots were harvested individually and their seed yields weighed.

Seed transmission. For each experiment, subsamples of 200 (experiments 1 and 2) or 300 (experiments 3 to 5) seeds from each plot were combined for all plots of the same treatment and germinated in trays, and leaf samples from seedlings were tested by ELISA individually or in groups of 2 to 10 . For each combined seed sample from each treatment, the following numbers of seeds were tested: in experiments 1 and 2, 0.3\% infected seed with or without insecticide (500 seeds in groups of 10); 0.7, 1.1, and $1.4 \%$ (experiment 1 ) and $0.6,0.9$, and $1.1 \%$ (experiment 2 ) simulated infected seed (400 seeds in groups of 5); $2.2 \%$ (experiment 1) and $1.7 \%$ (experiment 2) simulated and $6.5 \%$ infected seed sown (200 seeds in groups of 2); in experiment 3,0.1\% infected seed with or without insecticide and $0.25 \%$ infected seed $(1,000$ seeds in groups of 10); 0.5 and $1 \%$ infected seed $(1,100$ seeds in groups of 10); 2, 4, and $8 \%$ (800 seeds in groups of 2); in experiment 4 , with $8.2 \%$ infected seed (450 seeds in groups of 5) and $0.5 \%$ infected seed (200 seeds in groups of 10); and in experiment 5, with $8.2 \%$ infected seed (200 seeds individually) and $0.5 \%$ infected seed (180 seeds in groups of 2$)$. With each experiment, seed transmission rates in harvested seed (= output rates) were compared with those in the seed originally sown (= input rates).
Statistical analysis. For experiments 1 to 3, data from each plot for area under the pathogen progress curve (AUPPC), angular transformed percent PSbMV incidence, and seed yield were subjected to analysis of variance (ANOVA) using Genstat for Windows, release 10. Linear regression was used to relate final PSbMV incidence assessments $(x)$ to data for seed yield, yield gap, and 1,000-seed weight using mean results for each treatment (y). Coefficient of determination $\left(R^{2}\right), F$ tests, and standard errors of the $y$-estimate were determined. Yield gaps were measured by taking the maximum potential yield in each experiment (i.e., the best individual plot yield) and subtracting the yield obtained from each of the other individual plots $(40,42)$. Linear regression was also used to relate PSbMV incidence assessments at the growth stage just before flowering $(x)$ to data for percent seed transmission because, when infection occurs at or after flowering, the probability that PSbMV will enter developing pea seed resulting in seed transmission diminishes greatly (53-55). The growth stage sampled just before flowering was at 78 DAS (experiment 1), 63 DAS (experiment 2), and 75 DAS (experiment 3). For experiments 4 and 5, angular transformed final (90 DAS, experiment 4) or 78 DAS and penultimate (98 DAS, experiment 5) percent PSbMV incidence, AUPPC, and yield data were subjected to ANOVA. Linear regression was used to relate PSbMV incidence assessments at the growth stage just before flowering $(x)$ at 69 DAS (experiment 4) and 98 DAS (experiment 5) to data for percent seed transmission.

\section{RESULTS}

Plant densities. Plant establishment was an average of 43, 57, and 67 plants $/ \mathrm{m}^{2}$ in experiments 1,2 , and 3, respectively.

Symptoms and spread. Experiment 1. Patches of partially stunted pea plants with leaf pallor were often noticeable surrounding infection foci consisting of plants with seedborne infection or infector transplants. Vein clearing in newly invaded leaves and faint leaf mosaic was sometimes also visible initially but tended to fade later. Seed-infected plants were very stunted. However, the most noticeable difference between treatments was that both types of plots sown with $0.3 \%$ infected seed were tall with a uniform, flat canopy and vigorous growth, whereas those with the most primary infection foci $(1.4$ to $6.5 \%)$ had a pale appearance, with uneven canopies and obvious depressions containing partially stunted plants, especially those with $6.5 \%$ seedborne infection (Fig. 2). At 22 DAS, green peach aphids (Myzus persicae) were found colonizing Raphanus raphanistrum (wild radish) plants growing among the canola plants in the buffer surrounding the plots. By 50 DAS, winged and colonizing green peach aphids were present in large numbers on canola plants within the buffers, and unidentified winged aphids were first seen on plants within plots. Aphids were never observed colonizing pea plants during the experiment.

The magnitude of spread and final incidence of PSbMV within a plot depended upon the number of primary infection foci present. In plots sown with $6.5 \%$ infected seed, there was rapid

TABLE 2. Rainfall and temperature data for experiments 1 to 5

Rainfall and temperature data ${ }^{\mathrm{z}}$

\begin{tabular}{|c|c|c|c|c|c|c|c|c|c|c|c|c|}
\hline \multirow[b]{2}{*}{$\begin{array}{l}\text { Exp } \\
\text { (year) }\end{array}$} & \multicolumn{2}{|c|}{ January-February } & \multicolumn{2}{|c|}{ March-April } & \multicolumn{2}{|c|}{ May-June } & \multicolumn{2}{|c|}{ July-August } & \multicolumn{2}{|c|}{ September-October } & \multicolumn{2}{|c|}{ November-December } \\
\hline & $\begin{array}{l}\text { Rainfall } \\
(\mathrm{mm})\end{array}$ & $\begin{array}{l}\text { Temp } \\
\left({ }^{\circ} \mathrm{C}\right)\end{array}$ & $\begin{array}{l}\text { Rainfall } \\
(\mathrm{mm})\end{array}$ & $\begin{array}{l}\text { Temp } \\
\left({ }^{\circ} \mathrm{C}\right)\end{array}$ & $\begin{array}{c}\text { Rainfall } \\
(\mathrm{mm})\end{array}$ & $\begin{array}{l}\text { Temp } \\
\left({ }^{\circ} \mathrm{C}\right)\end{array}$ & $\begin{array}{c}\text { Rainfall } \\
(\mathrm{mm})\end{array}$ & $\begin{array}{l}\text { Temp } \\
\left({ }^{\circ} \mathrm{C}\right)\end{array}$ & $\begin{array}{c}\text { Rainfall } \\
(\mathrm{mm})\end{array}$ & $\begin{array}{l}\text { Temp } \\
\left({ }^{\circ} \mathrm{C}\right)\end{array}$ & $\begin{array}{c}\text { Rainfall } \\
(\mathrm{mm})\end{array}$ & $\begin{array}{l}\text { Temp } \\
\left({ }^{\circ} \mathrm{C}\right)\end{array}$ \\
\hline $2(2005)$ & 0.2 & $16.2-32.9$ & 40 & $15.7-28.8$ & 174.4 & $10.6-18.6$ & 175.2 & $6.5-15.9$ & 85 & $6.8-18.4$ & 3.8 & $13.5-26.0$ \\
\hline $3(2006)$ & 172.2 & $15.1-29.2$ & 29.4 & $11.5-25.6$ & 33.4 & $4.7-18.8$ & 120.4 & $6.0-17.0$ & 37.6 & $7.7-21.6$ & 28.6 & $14.2-29.8$ \\
\hline 4 (2007) & 20.4 & $17.4-33.2$ & 12.6 & $13.9-27.6$ & 39.8 & $7.0-18.1$ & 78 & $6.1-17.4$ & 45.2 & $7.6-22.3$ & 17.2 & $14.0-29.6$ \\
\hline $5(2007)$ & 198.4 & $15.7-29.6$ & 146.2 & $12.7-24.2$ & 82 & $8.4-16.9$ & 117.8 & $7.6-17.8$ & 117 & $8.2-20.0$ & 28.2 & $12.0-25.0$ \\
\hline
\end{tabular}

${ }^{\mathrm{z}}$ Rainfall = mean 2-monthly rainfall data and Temp = mean 2-monthly minimum-maximum temperature data for each experiment (Exp). 
spread of PSbMV, such that $28 \%$ of plants were infected by 64 DAS (Fig. 3A). In contrast, at 64 DAS spread was slower in the other treatments, reaching only 0 to $7 \%$. By 106 DAS, PSbMV incidence had reached $97 \%$ in plots sown with $6.5 \%$ infected seed, 61 to $69 \%$ in plots with 1.4 and $2.2 \%$ simulated seedborne infection, 38 to $40 \%$ in plots with 0.7 and $1.1 \%$ simulated seed infection, and 4 to $9 \%$ in plots with $0.3 \%$ seed infection (Table 3). In plots sown with $6.5 \%$ infected seed, both final PSbMV incidence and AUPPC were significantly greater than those in all other treatments. With the two treatments sown with $0.3 \%$ infected seed, final PSbMV incidence and AUPPC were significantly smaller than those for all other treatments. Final PSbMV incidence and AUPPC values were also significantly different when those for treatments with 0.7 and $1.1 \%$ simulated seedborne infection were compared with those for 1.4 and $2.2 \%$ simulated infection (Table 3 ). In plots sown with $0.3 \%$ infected seed, there was no significant difference in final incidence or AUPPC attributable to regular insecticide application.

Experiment 2. PSbMV symptoms in pea plants and the appearance of plots belonging to the different treatments were as in experiment 1 . By $49 \mathrm{DAS}$, winged and colonizing green peach aphids were present in large numbers on canola plants within the buffers that surrounded the plots, and unidentified winged aphids were first seen on pea plants within plots. As in experiment 1, aphids were never observed colonizing pea plants during the experiment.

As in experiment 1, magnitude of virus spread and final incidence depended upon the number of primary infection foci present in plots. Spread occurred rapidly in plots sown with $6.5 \%$ infected seed, such that $35 \%$ of plants were infected by 63 DAS. Incidence at 63 DAS in the other treatments was only 0.3 to $9 \%$ (Fig. 3B). By 93 DAS, incidence reached 76 and $98 \%$ in plots with $1.7 \%$ simulated seedborne infection or sown with $6.5 \%$ infected seed, respectively (Table 3), but only 6 to $48 \%$ in the other treatments. In plots sown with $6.5 \%$ infected seed, both final incidence and AUPPC were significantly greater than those in all other treatments. With plots with $1.7 \%$ simulated seedborne infection, both values were significantly greater than those in plots of all treatments with smaller initial infection incidences. With the two treatments sown with $0.3 \%$ infected seed, final incidence and AUPPC were significantly smaller than those for all other treatments. When final percent incidence values for treatments with 0.6 to $1.1 \%$ simulated seedborne infection were compared, they were not significantly different from each other. However, when AUPPC values for 0.6 and $1.1 \%$ simulated seedborne infection were compared, they were significantly different from each other (Table 3 ). As in experiment 1 , there was no significant difference attributable to insecticide application in plots sown with $0.3 \%$ infected seed.

Experiment 3. PSbMV spread was delayed in all treatments (Fig. 3C). Infection was mostly symptomless, but patches of PSbMV-infected plants with faint mosaic, leaf pallor, and mild stunting were also observed, especially in plots sown with $8 \%$ infected seed. In contrast to the situation with experiments 1 and 2 , obvious differences in overall plot appearance were absent between treatments. No colonizing aphids were observed on the pea or canola buffer plants, and winged aphids (unidentified) were not observed on pea plants until 103 DAS, which represents a considerable delay compared with their date of first appearance in experiments 1 and 2 .

Virus spread started later and reached fewer plants than in experiments 1 and 2. Thus, by 103 DAS, PSbMV incidence had reached only $36 \%$ in plots sown with $8 \%$ infected seed and 27 to $28 \%$ in plots sown with 2 or $4 \%$ infected seed (Fig. 3C). Plots sown with 0.1 to $1 \%$ infected seed had final incidences of only 4 to $15 \%$. In plots sown with $8 \%$ infected seed, both final PSbMV incidence and AUPPC values were significantly greater than those in all other treatments (Table 3). In plots sown with 2 or $4 \%$ infected seed, final incidence values were significantly greater than those in all treatments with smaller initial infection incidences, while AUPPC values also discriminated significantly between plots with 2 and $4 \%$ initial infection. In turn, for plots sown with 0.5 or $1 \%$ infected seed, final incidence values were significantly greater than those for plots with 0.1 or $0.25 \%$ initial infection. With AUPPC, plots sown with $1 \%$ infected seed had significantly greater values than those with 0.1 to $0.25 \%$ initial infection but discriminated less well between plots with $0.5 \%$ initial infection (Table 3). There was no significant difference attributable to insecticide application in plots sown with $0.1 \%$ infected seed.

Experiments 4 and 5. In experiment 4, all plants were stunted due to drought conditions in July and August (Table 2). In cv.

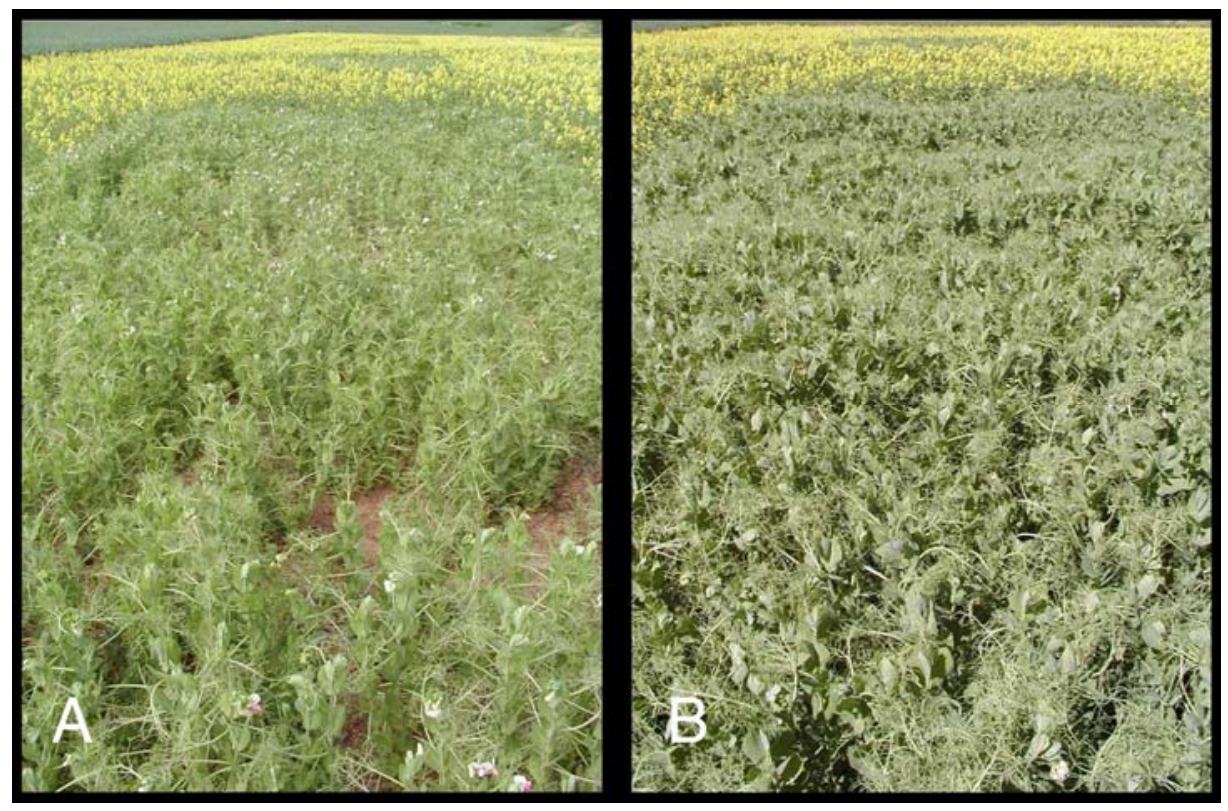

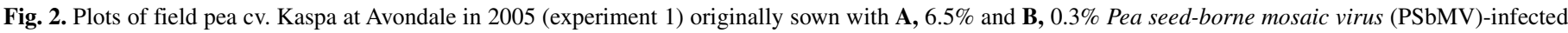

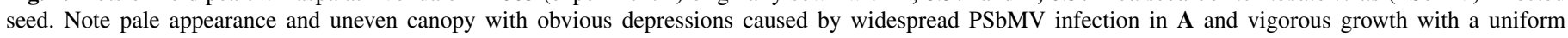
canopy in $\mathbf{B}$. 
Kaspa plots, most PSbMV-infected plants were asymptomatic but a few developed faint leaf mosaic. No virus was detected in cv. Yarrum. With cv. Kaspa, PSbMV spread slowly. By 90 DAS, plots sown with 8.2 or $0.5 \%$ infected seed reached incidences of 32 to 54 and only 3 to $4 \%$, respectively (Table 4; Fig. 3D). At 90 DAS, plots sown with $8.2 \%$ infected seed at the standard seeding rate without straw mulch or regular insecticide application had significantly greater incidences than those in the other three treatments in which cv. Kaspa seed was sown. Plots sown with $8.2 \%$ infected seed at the higher seeding rate with regular insecticide application and straw mulch had significantly greater incidences than those in the two treatments in which $0.5 \%$ infected seed was sown. There were no significant differences in incidence between the two treatments sown with $0.5 \%$ infected seed. AUPPC values discriminated less well between treatments but the two treatments sown with $8.2 \%$ infected seed still gave significantly greater AUPPC values than the other three.

In experiment 5, plots of the treatments sown with seed of $\mathrm{cv}$. Yarrum or $0.5 \%$ infected cv. Kaspa grew vigorously, with a uniform, flat canopy, whereas those sown with $8.2 \%$ infected seed had paler plants and an uneven canopy due to depressions centered on seed-infected plants. No virus was detected in cv. Yarrum but PSbMV spread substantially in all plots sown with cv. Kaspa. At 78 DAS, treatments sown with $8.2 \%$ infected seed had incidences of 26 to $73 \%$ while plots sown with $0.5 \%$ infected seed had incidences of 3 to $7 \%$ (Table 4; Fig. 3E). However, by 111 DAS, incidence reached 96 to $100 \%$ in all four treatments sown with cv. Kaspa seed regardless of initial seed infection level. At 78 and 98 DAS, plots sown with $8.2 \%$ infected seed at the standard seeding rate without straw mulch or insecticide had significantly greater incidences than those in the other three treatments in which cv. Kaspa seed was sown. At 78 DAS, plots sown with $8.2 \%$ infected seed at the higher seeding rate with straw mulch and insecticide had significantly greater incidences than those in the two treatments in which $0.5 \%$ infected seed was sown. There were no significant differences in incidence between the two treatments sown with $0.5 \%$ infected seed. At 98 DAS, plots sown with (i) $8.2 \%$ infected seed at the higher seeding rate with straw mulch and insecticide and (ii) $0.5 \%$ infected seed at standard seeding rate without straw mulch or insecticide had significantly greater incidences than those sown with $0.5 \%$ infected seed at the high seeding rate with straw mulch and insecticide. AUPPC values showed greater discrimination; each treatment value differing significantly from those of the other treatments.

Effect on seed yield. Experiment 1. Plots sown with $0.3 \%$ infected seed and given regular insecticide applications had significantly greater seed yields than those with 1.1 to $6.5 \%$ initial infection (Table 3). Plots sown with $0.3 \%$ infected seed without these insecticide applications had significantly greater seed yields than those with 2.2 to $6.5 \%$ initial infection. There were no significant seed yield differences between plots with $0.3 \%$ initial infection (without regular insecticide application) and those with 0.7 to $1.4 \%$ initial infection (final incidences 9 to $61 \%$ ), or between those with 0.7 to $6.5 \%$ initial infection (final incidences 38 to $97 \%$ ). When compared with those for plots sown with $0.3 \%$ infected seed with regular insecticide application, seed yield losses were 22 to $25 \%$ (6.5 and $2.2 \%$ initial infection) and $16 \%$ (1.1 and $1.4 \%$ initial infection). When compared with those for plots sown with $0.3 \%$ infected seed without regular insecticide application, seed yield losses were 18 to $21 \%$ (6.5 and $2.2 \%$ initial infection).

When data for the individual treatment means for the relationship between final incidence and yield (t/ha) were plotted, $84 \%$ of the variation was explained by percent incidence $(y=$ $-0.0073 x+2.8483, R^{2}=0.84, P=0.004$, SEE $y=0.1146$ ) (Fig. $4 \mathrm{~A})$. When mean yield gap data were substituted for mean seed yields, $82 \%$ of the variation was explained by percent incidence $\left(y=0.0077 x+0.4801, R^{2}=0.82, P=0.005\right.$, SEE $\left.y=0.1317\right)$
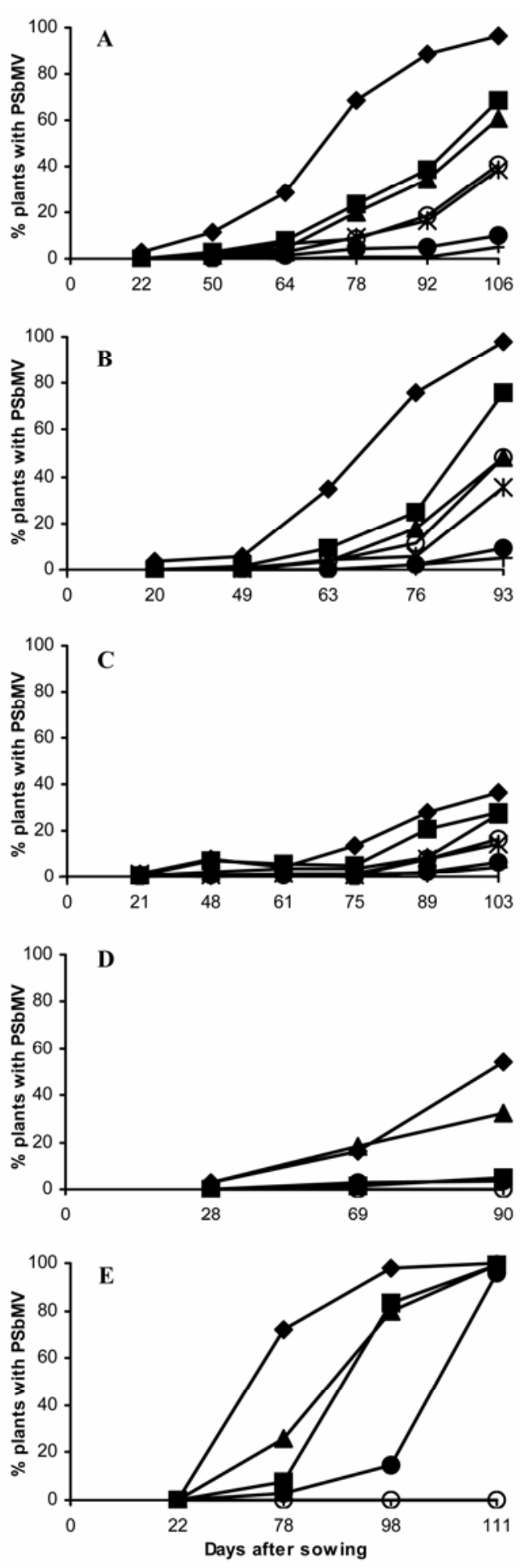

Fig. 3. Pathogen progress curves for Pea seed-borne mosaic virus spread in cv. Kaspa field pea plots. A, Avondale in 2005 (experiment 1); B, Badgingarra in 2005 (experiment 2); C, Avondale in 2006 (experiment 3); D, Merredin in 2007 (experiment 4); and E, Esperance in 2007 (experiment 5). Symbol codes for individual treatments: A, $0.3 \%$ initial infection with $(+)$ or without $(\bullet)$ regular insecticide sprays, $0.7 \%(\times), 1.1 \%(\bigcirc), 1.4 \%(\mathbf{\Delta}), 2.2 \%(\boldsymbol{\square})$, and $6.5 \%(\bullet)$ initial infection; $\mathbf{B}, 0.3 \%$ initial infection with $(+)$ or without $(\bullet)$ regular insecticide sprays, $0.6 \%(\times), 0.9 \%(\bigcirc), 1.1 \%(\mathbf{\Delta}), 1.7 \%(\mathbf{\square})$, and $6.5 \%(\diamond)$ initial infection; $\mathbf{C}, 0.1 \%$ initial infection with $(+)$ or without $(\bullet)$ regular insecticide sprays, $0.25 \%(\Delta), 0.5 \%(\mathbf{X}), 1 \%(\bigcirc), 2 \%(\boldsymbol{\Delta}), 4 \%(\boldsymbol{\square})$, and $8 \%(\diamond)$ initial infection; D and E, $8.2 \%$ initial infection sown at high seeding rate with straw mulch and regular insecticide sprays $(\boldsymbol{\Delta}), 8.2 \%$ initial infection sown at standard seeding rate without mulch or regular insecticide $(\diamond), 0.5 \%$ initial infection sown at high seeding rate with straw mulch and regular insecticide sprays $(\bullet), 0.5 \%$ initial infection at standard seeding rate without mulch or regular insecticide (ם), and cv. Yarrum at standard seeding rate without mulch or regular insecticide $(\bigcirc)$. 
(Fig. 4B) and, for each $1 \%$ increase in virus incidence, there was a yield decline of $7.7 \mathrm{~kg} / \mathrm{ha}$.

Experiment 2. Plots sown with $0.3 \%$ infected seed with or without regular insecticide applications or with $0.6 \%$ initial infection had significantly greater seed yields than those with 1.1 to $6.5 \%$ initial infection (Table 3). Also, plots with $0.9 \%$ initial infection had significantly greater seed yields than those with $6.5 \%$ initial infection. There were no significant seed yield differences between plots with 0.9 to $1.7 \%$ initial infection (final incidences 48 to $76 \%$ ) or between those with 1.1 to $6.5 \%$ initial infection (final incidences 48 to 98\%). When compared with those for plots sown with $0.3 \%$ infected seed with or without regular insecticide applications, seed yield losses were $25 \%$ from sowing $6.5 \%$ infected seed and 15 to $16 \%$ from 1.1 to $1.7 \%$ initial infection.

When data for the individual treatment means for the relationship between final incidence and yield (t/ha) were plotted, $81 \%$ of the variation was explained by percent incidence $(y=-0.0082 x+$ 3.0264, $R^{2}=0.81, P=0.005$, SEEy $=0.1443$ ) (Fig. 4D). When mean yield gap data were substituted for mean seed yields, $81 \%$

TABLE 3. Statistical analysis of Pea seed-borne mosaic virus incidence, yield, 1,000-seed weight, and seed transmission data from experiments 1 to $3{ }^{\mathrm{x}}$

\begin{tabular}{|c|c|c|c|c|c|}
\hline Initial infection $(\%)^{\mathrm{y}}$ & Final incidence $(\%)$ & $\mathrm{AUPPC}^{\mathrm{z}}$ & Yield (t/ha) & 1,000 -seed weight $(\mathrm{g})$ & Seed transmission $(\%)$ \\
\hline \multicolumn{6}{|l|}{ Experiment 1} \\
\hline $0.3+$ insecticide & $4(11.1) \mathrm{a}$ & $55 \mathrm{a}$ & $2.92 \mathrm{a}$ & $211.1 \mathrm{a}$ & 0.2 \\
\hline 0.3 & 9 (17.4) a & $219 \mathrm{a}$ & $2.75 \mathrm{ab}$ & $204.3 \mathrm{a}$ & 1 \\
\hline 0.7 & $38(38.1) b$ & $706 \mathrm{~b}$ & $2.61 \mathrm{abc}$ & $198.3 \mathrm{ab}$ & 2 \\
\hline 1.1 & $40(39.3) b$ & $784 \mathrm{~b}$ & $2.46 \mathrm{bc}$ & $190.8 \mathrm{~b}$ & 1 \\
\hline 1.4 & $61(51.6) \mathrm{c}$ & $1302 \mathrm{c}$ & $2.45 \mathrm{bc}$ & $189.2 \mathrm{bc}$ & 2 \\
\hline 2.2 & $69(56.5) c$ & $1516 \mathrm{c}$ & $2.18 \mathrm{c}$ & $186.1 \mathrm{bc}$ & 3 \\
\hline 6.5 & $97(81.1) \mathrm{d}$ & $3557 \mathrm{~d}$ & $2.26 \mathrm{c}$ & $176.7 \mathrm{c}$ & 11 \\
\hline$P$ & $<0.001$ & $<0.001$ & 0.028 & $<0.001$ & $\ldots$ \\
\hline LSD & $(8.26)$ & 331.3 & $(0.44)$ & 13.38 & $\ldots$ \\
\hline df & 24 & 24 & 24 & 24 & $\ldots$ \\
\hline \multicolumn{6}{|l|}{ Experiment 2} \\
\hline $0.3+$ insecticide & $6(13.7) \mathrm{a}$ & $88 \mathrm{a}$ & $2.91 \mathrm{a}$ & $201.9 \mathrm{a}$ & 1 \\
\hline 0.3 & 9 (17.7) a & $112 \mathrm{a}$ & $2.91 \mathrm{a}$ & $202.5 \mathrm{a}$ & 3 \\
\hline 0.6 & $36(36.7) b$ & $404 \mathrm{~b}$ & $2.99 \mathrm{a}$ & $194.4 \mathrm{ab}$ & 4 \\
\hline 0.9 & $48(44.1) b$ & $594 \mathrm{bc}$ & $2.65 \mathrm{ab}$ & $184.7 \mathrm{bc}$ & 5 \\
\hline 1.1 & $48(44.1) b$ & $656 \mathrm{c}$ & $2.47 \mathrm{bc}$ & $183.9 \mathrm{c}$ & 2 \\
\hline 1.7 & $76(60.5) c$ & $1039 \mathrm{~d}$ & $2.44 \mathrm{bc}$ & $176.0 \mathrm{c}$ & 6 \\
\hline 6.5 & $98(81.5) \mathrm{d}$ & $2365 \mathrm{e}$ & $2.17 \mathrm{c}$ & $178.0 \mathrm{c}$ & 17 \\
\hline$P$ & $<0.001$ & $<0.001$ & 0.010 & $<0.001$ & $\ldots$ \\
\hline LSD & (7.82) & 199.8 & $(0.466)$ & 10.07 & $\ldots$ \\
\hline df & 24 & 24 & 24 & 24 & $\ldots$ \\
\hline \multicolumn{6}{|l|}{ Experiment 3} \\
\hline $0.1+$ insecticide & $4(11.6) \mathrm{a}$ & $76 \mathrm{a}$ & $2.59 \mathrm{a}$ & $210.8 \mathrm{a}$ & 0.2 \\
\hline 0.1 & $6(14.6) \mathrm{a}$ & $88 a b$ & $2.21 \mathrm{~b}$ & $189.8 \mathrm{~b}$ & 0 \\
\hline 0.25 & $6(14.6) a$ & $107 \mathrm{ab}$ & $2.41 \mathrm{ab}$ & $196.2 \mathrm{~b}$ & 0.1 \\
\hline 0.5 & $14(21.9) b$ & $235 \mathrm{bc}$ & $2.16 \mathrm{bc}$ & $186.2 \mathrm{bc}$ & 0.2 \\
\hline 1 & $15(23.0) b$ & $276 \mathrm{c}$ & $2.33 \mathrm{ab}$ & $197.2 \mathrm{~b}$ & 0.3 \\
\hline 2 & $27(31.1) \mathrm{c}$ & $430 \mathrm{~d}$ & $2.25 \mathrm{~b}$ & $195.8 \mathrm{~b}$ & 0.4 \\
\hline 4 & $28(32.0) \mathrm{c}$ & $680 \mathrm{e}$ & $2.14 b c$ & $190.5 \mathrm{~b}$ & 0.8 \\
\hline 8 & $36(37.0) \mathrm{d}$ & $944 \mathrm{f}$ & $1.92 \mathrm{c}$ & $176.0 \mathrm{c}$ & 2 \\
\hline$P$ & $<0.001$ & $<0.001$ & 0.004 & 0.002 & $\ldots$ \\
\hline LSD & $(8.07)$ & 152.5 & $(0.284)$ & 13.22 & $\ldots$ \\
\hline $\mathrm{df}$ & 21 & 21 & 21 & 21 & $\ldots$ \\
\hline
\end{tabular}

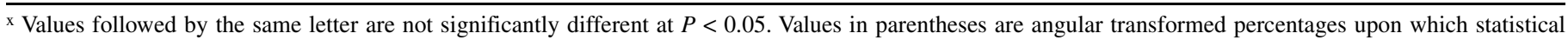
analyses are based.

y LSD = least significant difference.

z $\mathrm{AUPPC}=$ area under the pathogen progress curve.

TABLE 4. Statistical analysis of Pea seed-borne mosaic virus incidence, yield, and seed transmission data from experiments 4 and $5^{\mathrm{x}}$

\begin{tabular}{|c|c|c|c|c|c|c|c|c|c|}
\hline \multirow[b]{2}{*}{ Treatment ${ }^{\mathrm{y}}$} & \multicolumn{4}{|c|}{ Experiment 4} & \multicolumn{5}{|c|}{ Experiment 5} \\
\hline & $\begin{array}{c}\text { Incidence } \\
(90 \mathrm{DAS})(\%)\end{array}$ & AUPPC & $\begin{array}{l}\text { Yield } \\
\text { (t/ha) }\end{array}$ & $\begin{array}{c}\text { Seed } \\
\text { transmission }(\%)\end{array}$ & $\begin{array}{c}\text { Incidence } \\
(78 \mathrm{DAS})(\%)\end{array}$ & $\begin{array}{c}\text { Incidence } \\
(98 \mathrm{DAS})(\%)\end{array}$ & AUPPC & $\begin{array}{l}\text { Yield } \\
\text { (t/ha) }\end{array}$ & $\begin{array}{c}\text { Seed } \\
\text { transmission }(\%)\end{array}$ \\
\hline \multicolumn{10}{|l|}{ Cv. Kaspa, $8.2 \%$} \\
\hline 100 kg/ha (-) & $54(47) \mathrm{d}$ & $1,129 b$ & 0.08 & 10 & $73(58) \mathrm{d}$ & $98(83) \mathrm{d}$ & $5,893 \mathrm{e}$ & 1.83 & 36 \\
\hline $200 \mathrm{~kg} / \mathrm{ha}(+)$ & $32(35) \mathrm{c}$ & $977 \mathrm{~b}$ & 0.04 & 4 & $26(31) c$ & $79(63) \mathrm{c}$ & $3,722 \mathrm{~d}$ & 2.04 & 23 \\
\hline \multicolumn{10}{|l|}{ Cv. Kaspa, $0.5 \%$} \\
\hline 100 kg/ha (-) & $4(12) b$ & $132 \mathrm{a}$ & 0.08 & 0.8 & $7(15) b$ & $83(66) c$ & $3,087 \mathrm{c}$ & 1.74 & 25 \\
\hline $200 \mathrm{~kg} / \mathrm{ha}(+)$ & $3(10) b$ & $94 \mathrm{a}$ & 0.03 & 0.3 & $3(10) b$ & $50(45) b$ & $2,194 \mathrm{~b}$ & 1.75 & 15 \\
\hline \multicolumn{10}{|l|}{ Cv. Yarrum, $0 \%$} \\
\hline 100 kg/ha (-) & $0(0.6) \mathrm{a}$ & $0 \mathrm{a}$ & 0.07 & $\ldots$ & $0(0.6) \mathrm{a}$ & $0(0.6) \mathrm{a}$ & $0 \mathrm{a}$ & 2.03 & $\ldots$ \\
\hline$P$ & $<0.001$ & $<0.001$ & ns & $\ldots$ & $<0.001$ & $<0.001$ & $<0.001$ & ns & $\ldots$ \\
\hline $\mathrm{LSD}^{\mathrm{z}}$ & $(5.0)$ & 219.2 & $\ldots$ & $\ldots$ & $(9.2)$ & $(5.3)$ & 507.0 & $\ldots$ & $\ldots$ \\
\hline df & 8 & 8 & $\ldots$ & $\ldots$ & 8 & 8 & 8 & $\ldots$ & $\ldots$ \\
\hline
\end{tabular}

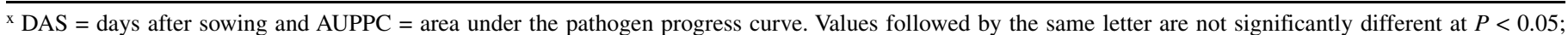
ns $=$ not significant. Values in parentheses are angular transformed percentages upon which statistical analyses are based.

y $\%=$ percent infected seed, $\mathrm{kg} / \mathrm{ha}=$ seeding rate; without straw mulch and insecticide $(-)$ or with straw mulch and insecticide $(+)$.

${ }^{\mathrm{z}} \mathrm{LSD}=$ least significant difference. 
of the variation was explained by percent incidence $(y=0.0082 x+$ $0.4469, R^{2}=0.81, P=0.005$, SEEy $=0.1445$ ) (Fig. 4E) and, for each $1 \%$ increase in virus incidence, there was a yield decline of $8.2 \mathrm{~kg} / \mathrm{ha}$.

Experiment 3. Plots sown with $0.1 \%$ infected seed with regular insecticide application had significantly greater seed yields than plots sown with $0.1 \%$ infected seed without regular insecticide applications or with 0.5 and 2 to $8 \%$ initial infection, but their yields were not significantly different than those in plots with 0.25 and $1 \%$ initial seedborne infection (Table 3 ). The seed yields in plots sown with $0.1 \%$ infected seed without regular insecticide application were significantly greater than those of plots sown with $8 \%$ infected seed but not significantly different than those for treatments with 0.25 to $4 \%$ initial seedborne infection. Plots sown with $8 \%$ infected seed had yields that were significantly smaller than those of all treatments except those with 0.5 and $4 \%$ seedborne infection. When compared with those for plots sown with $0.1 \%$ infected seed with regular insecticide application, seed yield losses were 13 to $17 \%(0.1,0.5$, and 2 to $4 \%$ initial infection) and $27 \%$ (8\% initial infection). When compared with those for plots sown with $0.1 \%$ infected seed without regular insecticide application, the seed yield loss value from sowing $8 \%$ infected seed was $13 \%$.

Seed yield for plots sown with $0.1 \%$ infected seed without regular insecticide application was $13 \%$ smaller than that for plots sown with the same seed with these insecticide applications, yet the difference in final PSbMV incidence was only $2 \%$. Thus, regular insecticide application controlled an insect other than aphid vectors (which did not colonize the plots) that reduced yields in most treatments without insecticides. The only other insect pest seen damaging the plots was pea weevil, suggesting that the blanket sprays against this pest should have started earlier. When data for the treatment means with and without those for plots sown with $0.1 \%$ infected seed with regular insecticide application were used to plot the relationships between final incidence and yield (t/ha) or final incidence and yield gaps, neither were related significantly.

Experiments 4 and 5. In experiment 4, the seed yields obtained were very low $(<80 \mathrm{~kg} / \mathrm{ha})$ due to poor plant growth resulting from drought conditions in July and August (Tables 2 and 4). No significant differences between the seed yields were obtained with the different treatments in either experiment.

Effect on individual seed weight. Experiments 1 and 2. In experiments 1 and 2, the mean 1,000-seed weight values for both treatments sown with $0.3 \%$ infected seed were significantly greater than those from treatments with 0.9 to $6.5 \%$ initial infection but not from that for the treatment with $0.6 \%$ initial infection (Table 3 ). However, in both experiments, the values for treatments with 1.4 to $6.5 \%$ (experiment 1 ) or 0.9 to $6.5 \%$ (experiment 2) initial infection were not significantly different from each other. In experiment 1 , there was a 7 to $14 \%$ (or 10 to $16 \%$ ) decrease in seed weight when the values for the treatment with $0.3 \%$ initial infection without (or with) regular insecticide application were compared with those for treatments with 1.1 to $6.5 \%$ initial infection. In experiment 2 , when the values for the two treatments with $0.3 \%$ initial infection were compared with those for treatments with 0.9 to $6.5 \%$ initial infection, seed weight was decreased by 9 to $13 \%$ regardless of whether regular insecticide application was used with $0.3 \%$ initial infection.

When data for the treatment means in experiment 1 were used to plot the relationship between final incidence and 1,000-seed weight, $94 \%$ of the variation was explained by PSbMV incidence $\left(y=-0.3449 x+209.1, R^{2}=0.94, P<0.001\right.$, SEE $\left.y=3.110\right)$ (Fig. 4C). Similarly, when data for the treatment means in experiment 2 were used to plot the same relationship, $89 \%$ of the variation was explained by PSbMV incidence $\left(y=-0.304 x+202.66, R^{2}=0.89\right.$, $P<0.001$, SEEy $=3.8942)($ Fig. 4F).

Experiment 3. In experiment 3, the mean 1,000-seed-weight value for the treatment sown with $0.1 \%$ infected seed with regular insecticide application was significantly greater than those from all other treatments (Table 3). However, the 1,000-seed-weight value for the treatment sown with $0.1 \%$ infected seed without regular insecticide application only differed significantly from the value for the treatment sown with $8 \%$ infected seed. There were no significant 1,000-seed-weight differences between treatments sown with 0.1 to $4 \%$ infected seed. When the 1,000 -seed-weight values for the treatments sown with $0.1 \%$ infected seed without regular insecticide application and $8 \%$ infected seed were compared, the loss in seed weight attributable to PSbMV infection was $7 \%$. When data for the treatment means with or without those
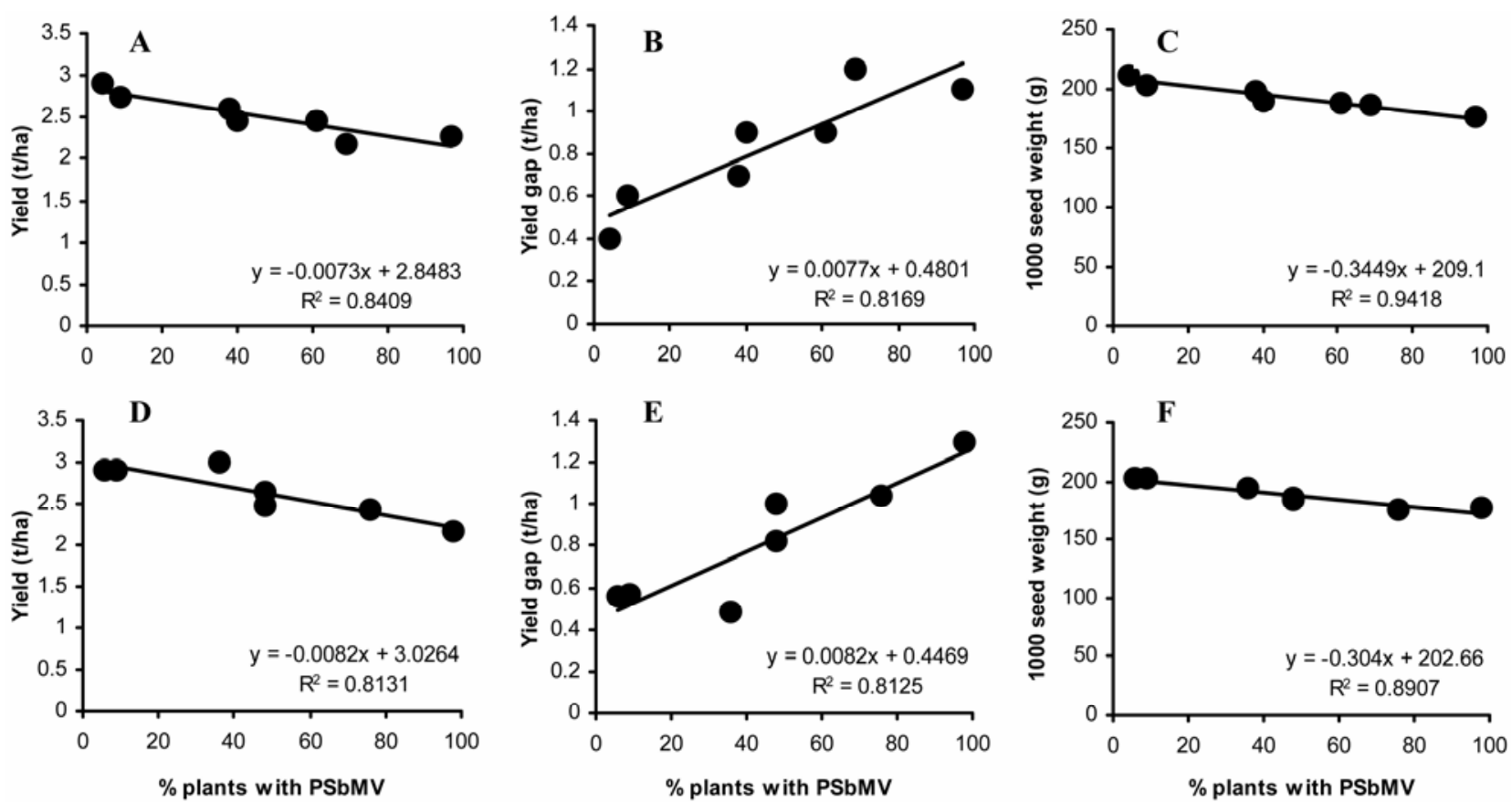

Fig. 4. Relationships between final incidence of Pea seed-borne mosaic virus and means of each treatment for $\mathbf{A}$, yield; $\mathbf{B}$, yield gaps; and $\mathbf{C}$, 1,000-seed weight at Avondale in 2005 (experiment 1); and D, yield; E, yield gaps; and F, 1,000-seed weight at Badgingarra in 2005 (experiment 2). 
for plots sown with $0.1 \%$ infected seed with regular insecticide application were used to plot the relationship between final PSbMV incidence and 1,000-seed-weight, they were not significantly related.

Seed transmission. In experiments 1 and 2, seed transmission of PSbMV was detected in seed samples harvested from all treatments (Table 2). The treatment sown with $0.3 \%$ infected seed with regular insecticide application had seed transmission rates of $0.2 \%$ (experiment 1 ) and $1 \%$ (experiment 2 ), whereas the seed transmission rates were $11 \%$ (experiment 1 ) and $17 \%$ (experiment 2 ) in treatments sown with $6.5 \%$ infected seed. For all other treatments, seed transmission rates were 1 to $3 \%$ (experiment 1 ) and 3 to $6 \%$ (experiment 2), increasing steadily with each stepwise increase in initial inoculum in the latter except in one instance. When data for the treatment means were used to plot the relationship between incidence at 78 DAS (experiment 1) or 63 DAS (experiment 2) and seed transmission, 96\% of the variation was explained by PSbMV incidence (experiment 1: $y=$ $0.1529 x+0.2603, R^{2}=0.96, P<0.001$, SEE $y=0.7429$; experiment 2: $y=0.4259 x+2.1496, R^{2}=0.96, P<0.001$, SEE $y=$ 1.1408) (Fig. 5A and B).

In experiment 3, seed transmission rates in seed samples harvested from plots were 0 to $0.8 \%$ for treatments sown with 0.1 to $4 \%$ infected seed but reached $2 \%$ for the treatment sown with $8 \%$ infected seed (Table 3). Thus, unlike the situation in experiments 1 and 2 where input seed transmission rates were mostly smaller than output rates, in experiment 3 , input seed transmission rates were mostly greater than output rates. When data for the treatment means were used to plot the relationship between incidence at 75 DAS and seed transmission, $99 \%$ of the variation was explained by PSbMV incidence $(y=0.0653 x+$ 0.0387, $R^{2}=0.99, P<0.001$, SEEy $=0.0663$ ) (Fig. 5C).

In experiments 4 and 5, seed transmission rates in seed samples harvested from plots sown with $0.5 \%$ infected seed were 0.3 to
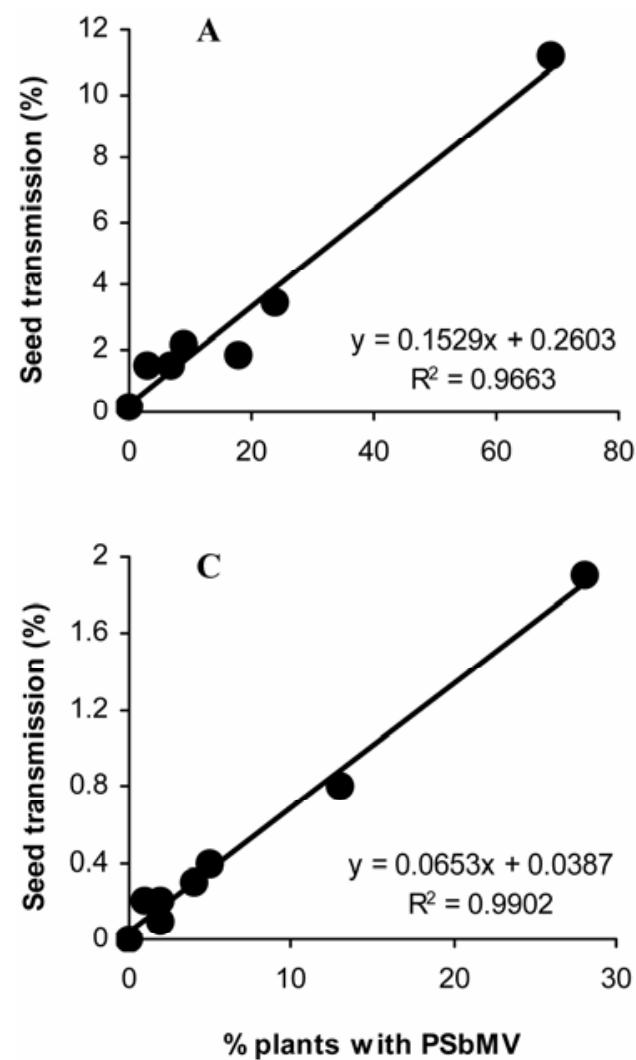

0.8 and 15 to $25 \%$, respectively (Table 4 ). For treatments sown with $8.2 \%$ infected seed, the corresponding transmission rates were 4 to 10 and 23 to $36 \%$, respectively. When all data for the treatment means were combined and used to plot the relationship between incidence at 69 DAS (experiment 4) and 98 DAS (experiment 5) and seed transmission, 95\% of the variation was explained by PSbMV incidence $\left(y=0.3219 x+0.2577, R^{2}=0.95\right.$, $P<0.001$, SEEy $=3.0757$ ) (Fig. 5D).

\section{DISCUSSION}

This study illustrates the kind of field-based research needed with pathosystems involving seedborne viruses to (i) demonstrate and quantify the yield losses and extent of seed infection likely to arise when seed stocks with different amounts of seedborne virus infection are sown and (ii) determine seed infection thresholds. We used the PSbMV-field pea pathosystem to show that, despite the subtleness of the symptoms induced, considerable yield losses can result from the epidemics that occur when seed stocks infected to different extents are sown in the field. Naturally occurring migrant winged aphid vectors acquired the virus from primary infection foci consisting of seed-infected pea plants, or infector transplants of faba bean that simulated seed-infected pea plants, and spread it to healthy plants. The magnitude of the epidemics that developed depended on the number of initial infection foci present to act as sources for secondary virus spread and on climatic conditions which influenced the timing of first arrival of migrant aphid vectors (Table 5). In turn, the extent of the yield losses and amount of infection in harvested seed both depended on the amount of PSbMV spread. Output seed transmission rates were mostly greater than input rates under conditions conducive to early virus spread but smaller in a late-spread scenario. A seed infection threshold value was established for sowing crops in high risk zones.
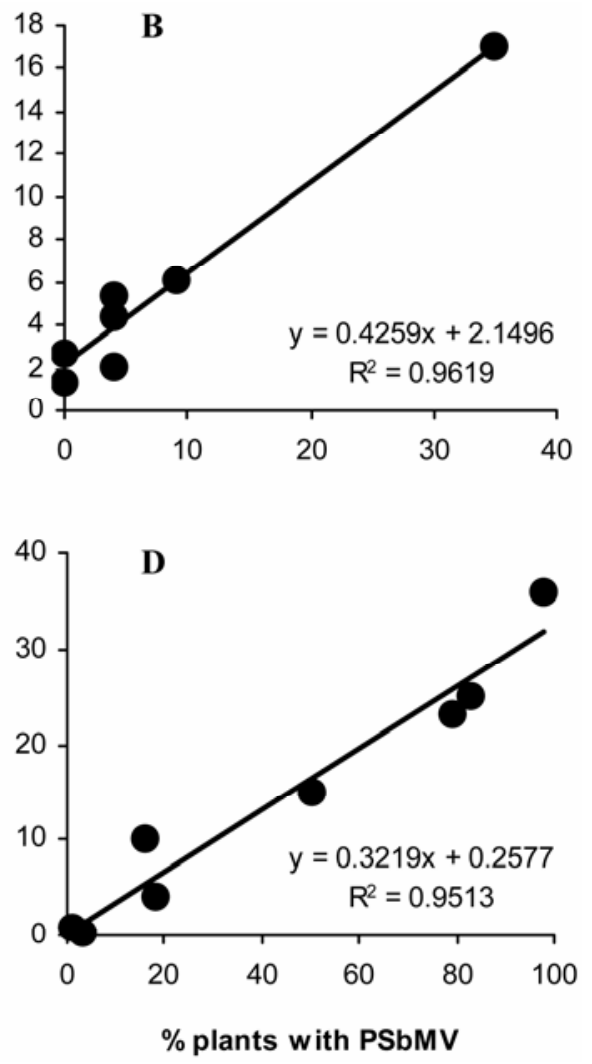

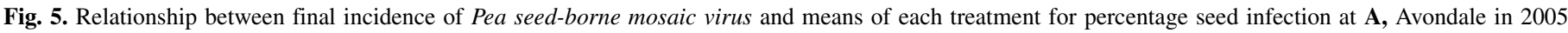

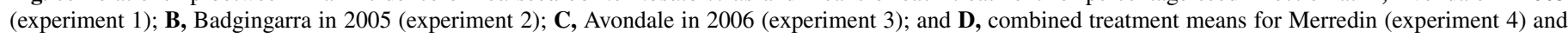
Esperance (experiment 5) in 2007. 
The experimental design used in different sites and years, which involved sowing seed stocks with differing amounts of seedborne (or simulated seedborne) infection in large, rectangular plots and surrounding them with large buffers of a tall nonhost crop, was effective, with little evidence of plot-to-plot spread of PSbMV by aphids. The shapes of the PSbMV pathogen progress curves obtained in experiments 1 to 3 showed that pea seedlings with seedborne infection and faba bean infector transplants behaved similarly as initial virus inoculum sources of different magnitudes (Fig. 3A to C). A similar experimental design was used previously with the CMV-narrow-leafed lupin pathosystem to establish the consequences of sowing seed stocks with different amounts of seedborne infection $(7,24,25,28)$. Healthy field pea seed stocks were unavailable; therefore, control treatments in experiments 1 to 3 consisted of plots sown with 0.1 to $0.3 \%$ infected seed with or without regular insecticide applications. As expected for a nonpersistently aphid-borne virus, such applications did not suppress spread by migrant vector aphids significantly $(8,45,52)$, although final incidences were always slightly smaller with than without the insecticide applications within control plots. However, although differences in seed yield values between these two treatments were not significantly different in 2005, due to tardy initiation of blanket insecticide sprays to all plots to control pea weevil, those for the treatment with regular insecticide applications were significantly greater in 2006 . Therefore, to remove any possibility that control of other pests by insecticide might be influencing them, yields from plots sown with 0.1 to $0.3 \%$ infected seed without regular insecticide application were always used as a base in calculating percent yield loss values for other treatments. Such calculations marginally underestimate the actual impact of PSbMV on yield because final incidence values in these plots were 6 to $9 \%$.

When field pea plots were sown with seed lots with actual or simulated seed transmission rates of 0.3 to $6.5 \%$ (2005) or 0.1 to $8 \%$ (2006), the higher the amount of primary inoculum within plots the greater the rate of PSbMV epidemic development, final virus incidence, and resulting seed yield losses. Thus, under conditions conducive to early virus spread (2005), sowing $6.5 \%$ infected seed resulted in yield losses of up to $25 \%$, and yield losses were 15 to $21 \%$ with 1.1 to $2.2 \%$ initial infection (Table 5); for each $1 \%$ increase in incidence, there was a yield decline of 7.7 to $8.2 \mathrm{~kg} / \mathrm{ha}$. In contrast, when conditions were not conducive to early virus spread (2006), sowing $8 \%$ infected seed resulted in smaller yield losses $(13 \%)$ and there were no significant yield decreases from sowing 1 to $4 \%$ infected seed. Yield loss was due to a combination of diminished seed weight and production of fewer seed. Differences in rate of virus spread and final incidence influenced the magnitude of infection in harvested seed markedly, with output PSbMV seed transmission rates being mostly greater than input rates in 2005 ( 1 to $17 \%$ ) but smaller than input rates in 2006 (only 0.2 to $2 \%$ ). This difference between a later spread and smaller final incidence scenario (2006) and the opposite scenario (2005) reflects not only the proportion of plants infected but also the relationship between the growth stage at which a pea plant first becomes infected and seed transmission rate. The earlier it becomes infected, the higher the percentage of seeds that transmit it to seedlings, with infection at or after flowering greatly diminishing the probability of seed transmission (53-55). We did not quantify the extent of quality defects caused by PSbMV infection in seed harvested in these experiments, as was done previously with other experiments in the grain-belt region $(13,36)$; however, the predominant symptoms were always necrotic ring and line markings on the seed coat, while other seed symptoms were malformation, diminished size, and splitting.

Under the Mediterranean-type climatic conditions of the grain belt of southwest Australia, the timing and magnitude of rainfall events supporting plant growth in fall (March to May) in a locality is directly related to the date of first arrival of aphids in crops. When there is little or no rain at this time, very few plants are available to support aphids before crops are sown; therefore, they take longer to build up and arrive in crops much later $(25,38,50,51)$. In the CMV-lupin pathosystem, the temporal dynamics of epidemics, extent of the yield losses, and amount of infection in harvested seed depend particularly on the magnitude of fall rainfall, initial virus incidence in the seed sown, and time of sowing $(7,24,25,50)$. Findings with the PSbMV-field pea pathosystem in the same region closely resembled those with CMV and lupin. With experiments 1 and 2 in 2005, the combined March to May rainfall was 215 and $164 \mathrm{~mm}$, respectively, sowing was early, and aphids first arrived soon after crop emergence. PSbMV spread quickly in plots sown with $>1 \%$ infected seed, resulting in yield losses of up to $25 \%$ and seed transmission rates of up to $17 \%$ in harvested seed (Table 5). In contrast, with experiment 3 in 2006 at the same location as that used in experiment 1, the March to May rainfall was only $39 \mathrm{~mm}$, sowing was delayed by 30 days, and aphid arrival was delayed. In this drier start and later sowing scenario, rate of virus spread and final incidence were diminished and yield losses and seed transmission rates in harvested seed did not exceed 13 and $2 \%$, respectively.

Although localized small populations of pea aphid (Acyrthosiphon pisum), green-peach aphid (M. persicae), and cowpea aphid (Aphis craccivora) occasionally develop in field pea crops under some conditions, aphids rarely colonize pea crops in the grain-belt region (56), which explains the absence of colonizing aphids in any of our experiments. Potential aphid vectors in the grain belt include species that colonize other legumes: the above three species and the blue-green aphid (Acyrthosiphon kondoi), and the principal species that colonize nonlegumes in pastures and other crops: the turnip aphid (Lipaphis erysimi), corn aphid (Rhopalosiphum maidis), and oat aphid (R. padi) $(4,8,25,38,50$ $52)$. When winged aphid migrants visit crops, they can spread the virus as they fly through the crop, making brief shallow probes while searching for their preferred host plants. However, no studies have been done in the region to compare the relative efficiencies of different aphid species as PSbMV vectors, such as those done previously with CMV in lupin (4).

The field pea cultivar used in these field experiments, Kaspa, is the one grown most widely in southwest Australia. When samples

TABLE 5. Summary of different yield loss and seed transmission scenarios in experiments 1 to 3

\begin{tabular}{|c|c|c|c|c|}
\hline \multirow[b]{2}{*}{ Parameter ${ }^{\mathrm{x}}$} & \multicolumn{4}{|c|}{ Scenario $^{y}$} \\
\hline & 1 & 2 & 3 & 4 \\
\hline Rainfall in spring & High & High & Low & Low \\
\hline Initial PSbMV seed infection incidence (\%) & 6.5 & $1.1-2.2^{\mathrm{z}}$ & 8 & $1-4$ \\
\hline Migrant aphid first observed arrival date & Early (49-50 DAS) & Early (49-50 DAS) & Late (103 DAS) & Late (103 DAS) \\
\hline Final crop PSbMV infection incidence (\%) & $97-98$ & $40-76$ & 36 & $14-28$ \\
\hline Seed yield loss $(\%)$ & $18-25$ & $15-21$ & 13 & NS \\
\hline PSbMV infection incidence in seed harvested (\%) & $11-17$ & $1-6$ & 2 & $0.3-0.8$ \\
\hline
\end{tabular}

x PSbMV = Pea seed-borne mosaic virus.

y Scenarios 1 and $2=$ experiments 1 and 2 and scenarios 3 and $4=$ experiment 3 . DAS = days after sowing and NS = seed yield loss not statistically significant.

z Seed infection simulated using infector plants. 
from commercial seed stocks of this cultivar were tested for PSbMV infection, seed transmission rates of 0.5 to $47 \%$ were found and none of 33 seed stocks tested was without infection (13). Although individual plant symptoms caused by PSbMV are too subtle for farmers to recognize readily, healthy crops with a uniform, flat canopy and vigorous growth are easy for them to distinguish from infected crops with uneven canopies and obvious depressions containing stunted plants. The knowledge that seed stocks are commonly infected, uneven canopies are typical of widespread crop infection, virus infection damages seed quality, and, depending on the amount of infection in the seed sown, yield losses can be $25 \%$ or more, led to a national reappraisal of the importance of the pathogen. A seed testing service for farmers' samples is now widely used to identify seed stocks with high levels of infection and select ones with "safe", low seed transmission rates. The question arises as to what constitute "safe" threshold PSbMV incidences in pea seed to be sown in different risk zones. For CMV in lupin, the threshold determined by field experimentation is $<0.5 \%$ in seed for low-risk zones and $0 \%$ for high-risk zones, based on a 1,000-seed test $(24,25)$. In high-risk scenarios, $1.1 \%$ initial PSbMV infection in field pea resulted in a significant yield losses and initial infection of as little as $0.9 \%$ still significantly diminished 1,000-seed-weight (Tables 3 and 5); therefore, a $<0.5 \%$ seed infection threshold was established for seed stocks intended for sowing for food in high-risk zones. However, because crops sown with $0.3 \%$ infected seed gave rise to 1 to $3 \%$ seed infection in high-risk situations, a $0 \%$ seed infection threshold based on a 1,000-seed test was recommended for crops intended only to produce seed to be sown. However, because seed stocks with $<0.5 \%$ seed infection are rarely available, the problem for farmers in high-risk zones then becomes one of sourcing seed stocks with sufficiently low incidences from low-risk zones (principally low rainfall zones) or growing their own seed crops in such a way that PSbMV spread is minimized. Determination of seed infection thresholds suitable for low-risk zones in the grain belt requires further field experimentation.

How might farmers multiply their own seed crops safely in high-risk zones? An IDM approach would appear to hold greatest promise $(26,27)$ because only small areas would need to be sown, minimizing the cost of deploying multiple control measures. Apart from sowing seed stocks with minimal amounts of infection in isolation, combinations of other control measures that help suppress CMV spread in lupin crops in the region might also help diminish PSbMV spread in field pea crops. These include sowing at high seeding rates to establish dense crops, close row spacing, minimum tillage, retaining stubble, regular insecticide application, and manipulation of sowing date (25). In 2007, a combined treatment of sowing $0.5 \%$ infected seed at high seeding rate with straw mulch on the soil surface and regular insecticide application resulted in significantly slower rates of spread than any combined treatment in which $8.2 \%$ infected seed was sown. In one experiment, it also produced significantly slower spread than sowing $0.5 \%$ infected seed at standard seeding rate without straw mulch and regular insecticide application. However, the only combined treatment in which output seed transmission rate was smaller $(0.3 \%)$ than the input rate was when $0.5 \%$ infected seed was sown at high seeding rate with straw mulch and insecticide application. Also, this occurred when fall rainfall (March to May) was only $32 \mathrm{~mm}$, drought conditions followed, and aphid arrival was late. In contrast, with the other field experiment in 2007, fall rainfall was $180 \mathrm{~mm}$ and aphids arrived early. Further field experiments examining the effectiveness of different potential combinations of control measures are required before an effective IDM approach to growing field pea seed stocks with minimal amounts of seed infection can be devised.

Forecasting and decision support systems accessible via the internet were developed previously for CMV and Bean yellow mosaic virus (family Potyviridae; genus Potyvirus) in narrow- leafed lupin, and Barley yellow dwarf virus (family Luteoviridae; genus Luteovirus) in wheat (Triticum aestivum) in the grain belt region $(38,50,51)$. Such forecasting models use rainfall during late summer and fall to calculate an index of aphid build-up in each district before the growing season starts. The index is then used to help forecast the timing and magnitude of aphid migration into the crop, subsequent aphid movement within the crop, virus spread, yield (and quality) losses, and any infection of harvested seed. The epidemiological, yield loss, and seed infection data obtained under different climatic scenarios in this study and the seed infection threshold values deduced can be combined with other PSbMV spread data from the region and information on seed quality damage $(13,35,36)$ to develop a similar forecasting and decision support system for the PSbMV-field pea pathosystem in the grain belt region.

\section{ACKNOWLEDGMENTS}

We thank B. E. Gadja, M. A. Kehoe, D. O'Keefe, and staff at Avondale, Badgingarra, Esperance, and Merredin Research Stations for technical assistance. The Australian Grains Research and Development Corporation provided financial support.

\section{LITERATURE CITED}

1. Adams, D. B., and Kuhn, C. W. 1977. Seed transmission of peanut mottle virus in peanuts. Phytopathology 67:1126-1129.

2. Albrechtsen, S. E. 2006. Testing Methods for Seed Transmitted Viruses: Principles and Protocols. CABI International, Wallingford, UK.

3. Ali, A., and Randles, J. W. 1998. The effects of two pathotypes of pea seed-borne mosaic virus on the morphology and yield of pea. Australas. Plant. Pathol. 27:226-233.

4. Berlandier, F. A., Thackray, D. J., Jones, R. A. C., Latham, L. J., and Cartwright, L. 1997. Determining the relative roles of different aphid species as vectors of cucumber mosaic and bean yellow mosaic viruses in lupins. Ann. Appl. Biol. 131:297-314.

5. Bos, L. 1977. Seed borne viruses. Pages 39-65 in: Plant Health and Quarantine in International Transfer of Genetic Resources. W. B. Hewitt and L. Chiarappa, eds. CRC Press, Boca Raton, FL.

6. Bos, L., Hampton, R. O., and Makkouk, K. M. 1988. Viruses and virus diseases of pea, lentil, faba bean and chickpea. Pages 591-615 in: World Crops: Cool Season Food Legumes. R. J. Summerfield, ed. Kluwer Academic Publishers, Dordrecht, The Netherlands.

7. Bwye, A. M., Jones, R. A. C., and Proudlove, W. 1994. Effects of sowing seed with different levels of infection, plant density and the growth stage at which plants first develop symptoms on cucumber mosaic virus infection of narrow-leafed lupins (Lupinus angustifolius). Aust. J. Agric. Res. 45:1395-1412.

8. Bwye, A. M., Proudlove, W., Berlandier, F. A., and Jones, R. A. C. 1997. Effects of applying insecticides to control aphid vectors and cucumber mosaic virus in narrow-leafed lupins (Lupinus angustifolius). Aust. J. Exp. Agric. 37:93-102.

9. Chiko, A. W., and Zimmer, R. C. 1978. Effect of pea seed-borne mosaic virus on two cultivars of field pea grown in Manitoba. Can. J. Plant Sci. 58:1073-1080

10. Clark, M. F., and Adams, A. N. 1977. Characteristics of the microplate method of enzyme-linked immunosorbent assay for the detection of plant viruses. J. Gen. Virol. 34:475-483.

11. Cockbain, A. J., Cook, S. M., and Bowen, R. 1975. Transmission of broad bean stain virus and Echtes Ackerbohnenmosaik-Virus to field beans (Vicia faba) by weevils. Ann. Appl. Biol. 81:331-339.

12. Corbett, M. K., and Edwardson, J. R. 1957. Virus diseases of yellow lupins: preliminary investigation on control by use of a protecting border. Proc. Soil Crop Sci. Soc. Fla. 17:294-301.

13. Coutts, B. A., Prince, R. T., and Jones, R. A. C. 2008. Further studies on Pea seed-borne mosaic virus in cool-season crop legumes: responses to infection and seed quality defects. Aust. J. Agric. Res. 59:1130-1145.

14. Duncan, J. M., and Torrance, L., eds. 1992. Techniques for the Rapid Detection of Plant Pathogens. Blackwell Scientific, Oxford.

15. Edwardson, J. R., and Christie, R. G., eds. 1991. CRC Handbook of Viruses Infecting Legumes. CRC Press, Boca Raton, FL.

16. Fletcher, J. D., Russell, A. C., and Butler, R. C. 1999. Seed-borne cucumber mosaic virus in New Zealand lentil crops: yield effects and disease incidence. N. Z. J. Crop Hortic. Sci. 27:197-204.

17. Gibbs, A. J., and Gower, J. C. 1960. The use of a multiple-transfer method in plant virus transmission studies-some statistical points arising in the 
analysis of results. Ann. Appl. Biol. 48:75-83.

18. Grogan, R. G. 1980. Control of lettuce mosaic with virus-free seed. Plant Dis. 64:446-449.

19. Grogan, R. G. 1983. Lettuce mosaic virus control by use of virus-indexed seeds. Seed Sci. Technol. 11:1043-1049.

20. Hampton, R. O., and Mink, G. I. 1975. Pea seed-borne mosaic virus. CMI/AAB Descriptions of Plant Viruses, No. 146.

21. Johansen, E., Edwards, M. C., and Hampton, R. O. 1994. Seed transmission of viruses: current perspectives. Annu. Rev. Phytopathol. 32:363-386

22. Jones, A. T. 1980. Seed-borne viruses and the possibility of producing seed free from broad bean stain virus and Echtes AckerbohnenmosaikVirus. Pages 319-333 in: Vicia faba: Feeding Value, Processing and Viruses. D. A. Bond, ed. Martinus Nijhoff, The Hague, The Netherlands.

23. Jones, R. A. C. 1988. Seed-borne cucumber mosaic virus infection of narrow-leafed lupin (Lupinus angustifolius) in Western Australia. Ann. Appl. Biol. 113:507-518.

24. Jones, R. A. C. 2000. Determining 'threshold' levels for seed-borne virus infection in seed stocks. Virus Res. 71:171-183.

25. Jones, R. A. C. 2001. Developing integrated disease management strategies against non-persistently aphid-borne viruses: a model programme. Integr. Pest Manage. Rev. 6:15-46.

26. Jones, R. A. C. 2004. Using epidemiological information to develop effective integrated virus disease management strategies. Virus Res. 100:5-30.

27. Jones, R. A. C. 2006. Control of plant virus diseases. Adv. Virus Res. 67:205-244.

28. Jones, R. A. C., and Proudlove, W. 1991. Further studies on cucumber mosaic virus infection of narrow-leafed lupin (Lupinus angustifolius): seed borne infection, aphid transmission, spread and effects on grain yield. Ann. Appl. Biol. 118:319-329.

29. Jones, R. A. C., and Torrance, L., eds. 1986. Developments and Applications in Virus Testing. Developments in Applied Biology, Vol 1. Association of Applied Biologists, Wellesborne, UK.

30. Kaiser, W. J. 1973. Etiology and biology of viruses affecting lentil (Lens esculenta Moench.) in Iran. Phytopathol. Mediterr. 12:7-14

31. Kaiser, W. J., Danesh, D., Okhovat, M., and Mossahebi, H. 1968. Diseases of pulse crops (edible legumes) in Iran. Plant Dis. Rep. 52:687691.

32. Khetarpal, R. K., Bossennec, J. M., Burghofer, A., Cousin, R., and Maury, Y. 1988. Effect of pea seed-borne mosaic virus on yield of field pea. Agronomie 8:811-815.

33. Khetarpal, R. K., and Maury, Y. 1987. Pea seed-borne mosaic virus: A review. Agronomie 7:215-224.

34. Kraft, J. M., and Hampton, R. O. 1980. Crop losses from pea seed-borne mosaic virus in six processing pea cultivars. Plant Dis. 64:922-924.

35. Latham, L. J., and Jones, R. A. C. 2001. Incidence of virus infection in experimental plots, commercial crops and seed stocks of cool season crop legumes. Aust. J. Agric. Res. 52:397-413.

36. Latham, L. J., and Jones, R. A. C. 2001. Alfalfa mosaic and pea seedborne mosaic viruses in cool season crop, annual pasture and forage legumes: susceptibility, sensitivity and seed transmission. Aust. J. Agric. Res. 52:771-790.

37. Makkouk, K. M., Kumari S. G., and Bos, L. 1993. Pea seed-borne mosaic virus: occurrence in faba bean (Vicia faba) and lentil (Lens culinaris) in West Asia and North Africa, and further information on host range, transmission characteristics and purification. Neth. J. Plant Pathol. 99:115-124.
38. Maling, T., Diggle, A. J., Thackray, D. J., Siddique, K. H. M., and Jones, R. A. C. 2008. An epidemiological model for externally sourced vectorborne viruses applied to Bean yellow mosaic virus in lupin crops in a Mediterranean-type environment. Phytopathology 98:1280-1290.

39. Maury, Y., and Khetarpal, R. K. 1992. Pea seed-borne mosaic virus. Pages 74-92 in: Plant Diseases of International Importance, Diseases of Vegetables and Oil Seed Crops, Volume 2. H. S. Chaube, J. Kumar, A. N. Mukhopadhyay, and U.S. Singh, eds. Prentice Hall Inc., NJ.

40. McKirdy, S. J., Jones, R. A. C., and Nutter, F. W. 2002. Quantification of yield losses caused by Barley yellow dwarf virus in wheat and oats. Plant Dis. 86:769-773

41. Nutter, F. W., Pederson, V. D., and Timian, R. G. 1984. Relationship between seed infection by barley stripe mosaic virus and yield loss. Plant Dis. 77:363-366

42. Nutter, F. W., Teng, P. S., and Royer, M. H. 1993. Terms and concepts for yield, crop loss, and disease thresholds. Plant Dis. 77:211-215.

43. Ovenden, G. E., and Ashby, J. W. 1981. The effect of pea seed-borne mosaic virus on yield of peas. Proc. Agron. Soc. N. Z. 11:61-63.

44. Paguio, O. R., and Kuhn, C. W. 1974. Incidence and source of inoculum of peanut mottle virus and its effect on peanut. Phytopathology 64:60-64.

45. Perring, T. M., Gruenhagen, N. M., and Farrar, C. A. 1999. Management of plant viral diseases through chemical control of insect vectors. Annu. Rev. Entomol. 44:457-481.

46. Stace-Smith, R., and Hamilton, R. I. 1988. Inoculum thresholds of seedborne pathogens-viruses. Phytopathology 78:875-880.

47. Stevenson, W. R., and Hagedorn, D. J. 1970. Effect of seed size and condition on transmission of pea seed-borne mosaic virus. Phytopathology 60:1148-1149.

48. Stevenson, W. R., and Hagedorn, D. J. 1973. Further studies on seed transmission of pea seedborne mosaic virus in Pisum sativum. Plant Dis. Rep. 57:248-252.

49. Tomlinson, J. A. 1962. Control of lettuce mosaic virus by the use of healthy seed. Plant Pathol. 11:61-64.

50. Thackray, D. J., Diggle, A. J., Berlandier, F. A., and Jones, R. A. C. 2004. Forecasting aphid outbreaks and epidemics of Cucumber mosaic virus in lupin crops in a Mediterranean-type environment. Virus Res. 100:67-82.

51. Thackray, D. J., Diggle, A. J., and Jones, R. A. C. 2009. BYDV predictor: a simulation model to predict aphid arrival, epidemics of Barley yellow dwarf virus and yield losses in wheat crops in a Mediterranean-type environment. Plant Pathol. 58:186-202.

52. Thackray, D. J., Jones, R. A. C., Bwye, A. M., and Coutts, B. A. 2000. Further studies on the effects of insecticides on aphid vector numbers and spread of cucumber mosaic virus in narrow-leafed lupins (Lupinus angustifolius). Crop Prot. 19:121-139.

53. Wang, D., and Maule, A. J. 1992. Early embryo invasion as a determinant in pea of the seed transmission of pea seed-borne mosaic virus. J. Gen. Virol. 73:1615-1620

54. Wang, D., and Maule, A. J. 1994. A model for seed transmission of a plant virus: genetic and structural analyses of pea embryo invasion by pea seedborne mosaic virus. Plant Cell 6:777-787.

55. Wang, D., and Maule, A. J. 1997. Contrasting patterns in the spread of two seed-borne viruses in pea embryos. Plant J. 11:1333-1340.

56. White, P., Harries, M., Seymour, M., and Burgess, P., eds. 2005. Producing Pulses in the Northern Agricultural Region. Bull. No. 4656. Department of Agriculture for Western Australia, South Perth, Australia.

57. Zink, F. W., Grogan, R. G., and Welch, J. E. 1956. The effect of the percentage of seed transmission upon subsequent spread of lettuce mosaic virus. Phytopathology 46:662-664. 